\title{
Workshop Pemanfaatan Aplikasi Berbasis Komputer "CMI-SIPSMA Sistem Informasi Penilaian Sekolah" bagi Guru IPA Tingkat SMP di Sleman, Yogyakarta
}

\section{Workshop Use of Computer-Based Applications "CMI-SIPSMA Information System of School Assessment" For Science Teachers of SMP in Sleman, Yogyakarta}

\author{
Wita Setianingsih*, Dadan Rosana, Didik Setyawarno
}

Jurusan Pendidikan IPA FMIPA Universitas Negeri Yogyakarta, *Email: wita@uny.ac.id,

\begin{abstract}
Abstrak
Tujuan program pengabdian (PPM) ini adalah untuk meningkatkan penguasaan penggunaan aplikasi computer "CMI-SIPSMA" guru IPA di Sleman, Yogyakarta dalam bidang penilaian hasil belajar. Kegiatan pelatihan ini diperuntuk bagi guru-guru IPA di Sleman, Yogyakarta. Pelaksanaan kegiatan ini direncanakan di salah satu SMP di Sleman Yogyakarta yang dikolaborasikan dengan kegiatan MGMP atau pertemuan guru IPA secara rutin, sehingga memudahkan akses bagi semua guru yang akan mengikuti pelatihan ini. Pelaksanaan PPM pada hari Sabtu, 9 September 2017, di Laboratorium Komputer Jurusan Pendidikan IPA FMIPA UNY, mulai pukul 07.00 - 11.30. Kegiatan PPM dilaksanakan dengan cara tutorial (Tatap Muka), workshop, penugasan terstruktur, dan konsultasi via on-line. Hasil kegiatan PPM ini yaitu guru memiliki pemahaman dasar tentang problem dan solusi dalam implementasi penilaian berdasarkan K-13 dan memiliki kemampuan menggunakan aplikasi yang ada di CMI SIPSMA untuk analisis butir soal untuk menghasilkan butir soal yang berkualitas.
\end{abstract}

Kata kunci: CMI-SIPSMA, Penilaian, Guru IPA.

\begin{abstract}
The purpose of this program of dedication (PPM) is to increase the mastery of the use of computer application "CMI-SIPSMA" science teachers in Sleman, Yogyakarta in the field of assessment of learning outcomes. This training activity is intended for science teachers in Sleman, Yogyakarta. Implementation of this activity is planned in one of Junior High School in Sleman Yogyakarta which is collaborated with MGMP activity or IPA meeting regularly, making it easier for all teachers who will attend this training. Implementation of PPM on Saturday, September 9, 2017, at the Laboratory Computer Science Department IPA FMIPA UNY, starting at 07:00 to 11:30. PPM activities are conducted by way of tutorial (Tatap Muka), workshop, structured assignment, and consultation via on-line. The result of this PPM activity is that teachers have a basic understanding of the problems and solutions in the implementation of the assessment based on $K-13$ and have the ability to use existing applications in CMI SIPSMA for item analysis to produce quality items.
\end{abstract}

Keywords: CMI-SIPSMA, Assessment, Science Teacher.

\section{PENDAHULUAN}

Information Communication and Technology (ICT) atau yang dikenal dengan Teknologi Informasi dan Komunikasi (TIK) mempunyai banyak peranan dalam segala bidang tidak terkecuali dalam pendidikan. Kemajuan teknologi tersebut merupakan sesuatu yang tidak bisa kita hindari dalam kehidupan ini, karena kemajuan teknologi akan berjalan sesuai dengan kemajuanm ilmu pengetahuan. ICT telah menjadi pengalihfungsian buku, guru, dan sistem pengajaran yang sebelumnya masih bersifat konvensional. Setiap inovasi diciptakan untuk memberikan manfaat positif bagi manusia. Indonesia sebagai Negara berkembang juga tidak bisa lepas dari 
penggunaan ICT dalam bidang pendidikan baik dalam pembelajaran maupun dalam administrasi sekolah. Guru dan tenaga kependidikan di sekolah di pandang perlu untuk meningkatkan kompetensi dalam bidang pemanfaatan ICT.

Salah satu barometer kemajuan pendidikan di Indonesia adalah pemanfaatan teknologi komputer dalam dunia pendidikan. Beberapa aplikasi komputer telah dibuat oleh ahli ICT baik media maupun aplikasi untuk penilaian hasil belajar peserta didik. Teknologi berbasis komputer tersebut mampu memudahkan dalam berbagai aspek pendidikan. Guru sebagai unsur pelaksana pendidikan perlu untuk meningkatkan kompetensinya di bidang ICT untuk mengikuti perkembangan di era digital saat ini. Melihat realitas saat ini, pemanfaatan ICT dalam bidang penilaian masih relative sedikit jika dibandikan dengan pemanfaatan ICT dalam bidang pembelajaran di kelas. Pelatihan penggunaan aplikasi komputer untuk analisis hasil belajar dirasa sangat perlu untuk guru-guru saat ini.

Penggunaan aplikasi komputer di bidang evaluasi untuk memudahkan penilaian bagi guru sangat penting. Guru mampu melihat kondisi peserta didik secara lengkap dan cepat dengan aplikasi tersebut. Selain itu, semua bentuk administrasi terkait tugas guru akan mudah teratasi dengan penggunaan ICT. Penggunaan aplikasi komputer dalam bidang penilaian sebagian besar masih terbatas sekedar untuk mengetahui kualitas butir soal. Oleh karena itu, pelatihan dalam bentuk workshop perlu dilakukan untuk meningkatkan kompetensi terkait dengan tugas guru sekaligus untuk meningkatkan kompetensi dalam bidang ICT.

CMI-SIPSMA merupakan salah satu aplikasi berbasis computer untuk sistem informasi penilaian sekolah yang telah dikembangkan oleh Dr. Dadan Rosana, M.Si Dosen Pendidikan IPA FMIPA UNY yang dapat digunakan untuk membantu guru disekolah baik sistem pendidikan, pengelolaan, penilaian, laporan, bank soal, equating, dan aplikasi butir soal dengan pendekatan teori klasik dan teori respon butir. Aplikasi tersebut masih belum banyak digunakan di sekolah, sehingga perlu diadakan workshop atau pelatihan tentang penggunaan aplikasi tersebut. CMI-SIPSMA merupakan produk penelitian oleh Dr. Dadan Rosana, M.Si yang masih perlu disebarluaskan ke kalangan akademisi termasuk guru-guru di sekolah. Aplikasi tersebut sangat mudah digunakan, namun demikian para guru tetap memerlukan arahan langsung dari Tim Pengembang aplikasi tersebut. Perkembangan ICT yang sangat cepat perlu diimbangi dengan guru yang mampu menggunakan ICT tersebut dengan baik terlebih tuntutan kurikulum 2013 yang sedang berjalan sekarang.

Berbagai workshop dan pelatihan telah banyak diselenggarakan oleh pemerintah maupun dari internal sekolah dirasa masih perlu ditingkatkan. Hal itu disebabkan perkembangan ICT yang sangat cepat dalam berbagai aspek, sehingga guru perlu memiliki kompetensi ICT yang up to date. Kurikulum 2013 dari aspek penilaian menuntut agar guru mampu melalukan penilaian secara komprehensif baik penilaian kognitif, afektif, dan psikomor secara kontinyu dan terstruktur. Pelatihan peningkatan kompetensi guru dalam bidang ICT untuk program penilaian hasil belajar peserta Didik perlu dilalukan secara kontinyu oleh pemerintah maupun lembaga pendidikan termasuk oleh perguruan tinggi.

Yogyakarta sebagai kota pelajar menjadi sorotan untuk dijadikan studi banding dari berbagai sekolah di Indonesia. Berbagai pelatihan perlu ditingkatkan untuk meningkatkan kualitas proses pendidikan baik dalam aspek administrasi, proses pembelajaran, maupun penilaian hasil belajar siswa di daerah tersebut. Berdasarkan uraian tersebut, perlu diadakan workshop dalam bentuk pelatihan penggunaan aplikasi berbasis computer dalam bidang penilaian hasil belajar peserta didik. Disamping itu, pelatihan tersebut juga untuk meningkatkan kompetensi guru dalam 
mengimplementasikan Kurikulum 2013 di sekolah masing-masing.

\section{SOLUSI/TEKNOLOGI}

Kegiatan yang akan dilaksanakan adalah kegiatan pelatihan yang ditujukan bagi guru-guru IPA tingkat SMP di Sleman, Yogyakarta. Kegiatan pelatihan meliputi penyampaian materi yang meliputi konsep dasar penilaian dalam kurikulum 2013, materi panduan dasar penggunaan aplikasi CMI-SIPSMA, dan praktek menggunakan aplikasi CMI-SIPSMA dalam penilaian hasil belajar siswa. Kegiatan pelatihan ini diperuntuk bagi guru-guru IPA di Sleman, Yogyakarta. Pelaksanaan kegiatan ini direncanakan di salah satu SMP di Sleman Yogyakarta yang dikolaborasikan dengan kegiatan MGMP atau pertemuan guru IPA secara rutin, sehingga memudahkan akses bagi semua guru yang akan mengikuti pelatihan ini.

Masalah penguasaan atau keterampilan guru IPA dalam menggunakan aplikasi CMI-SIPSMA dapat diselesaikan dengan dilakukan dalam beberapa cara berikut:

1. Memberikan pemahaman secara utuh tentang penilaian berdasarkan kurikulum 2013.

2. Memberikan pelatihan CMI-SIPSMA pada pihak penyelenggara pendidikan yaitu guru-guru IPA tingkat SMP di Sleman Yogyakarta.

3. Memberikan bimbingan dan pendampingan secara langsung kepada guru IPA tingkat SMP dalam menggunakan aplikasi CMI-SIPSMA.

Ketiga alternatif tersebut dapat dilaksanakan dengan baik dengan berbagai pertimbangan sebagai berikut.

1. Penggunaan waktu jauh lebih efisien dan dapat dipraktekkan langsung di sekolah setelah pelatihan selesai dilaksanakan.

2. Guru IPA adalah manager kelas yang bertugas untuk mengimplementasikan kurikulum 2013.

Kegiatan akan dilaksanakan di salah satu SMP di Sleman, Yogyakarta. Pada saat pelaksanaan, monitoring, evaluasi dan refleksi dilaksanakan terus menerus untuk mencapai hasil kegiatan yang maksimal. Secara rinci, alur pemecahan masalah digambarkan dengan diagram berikut ini.

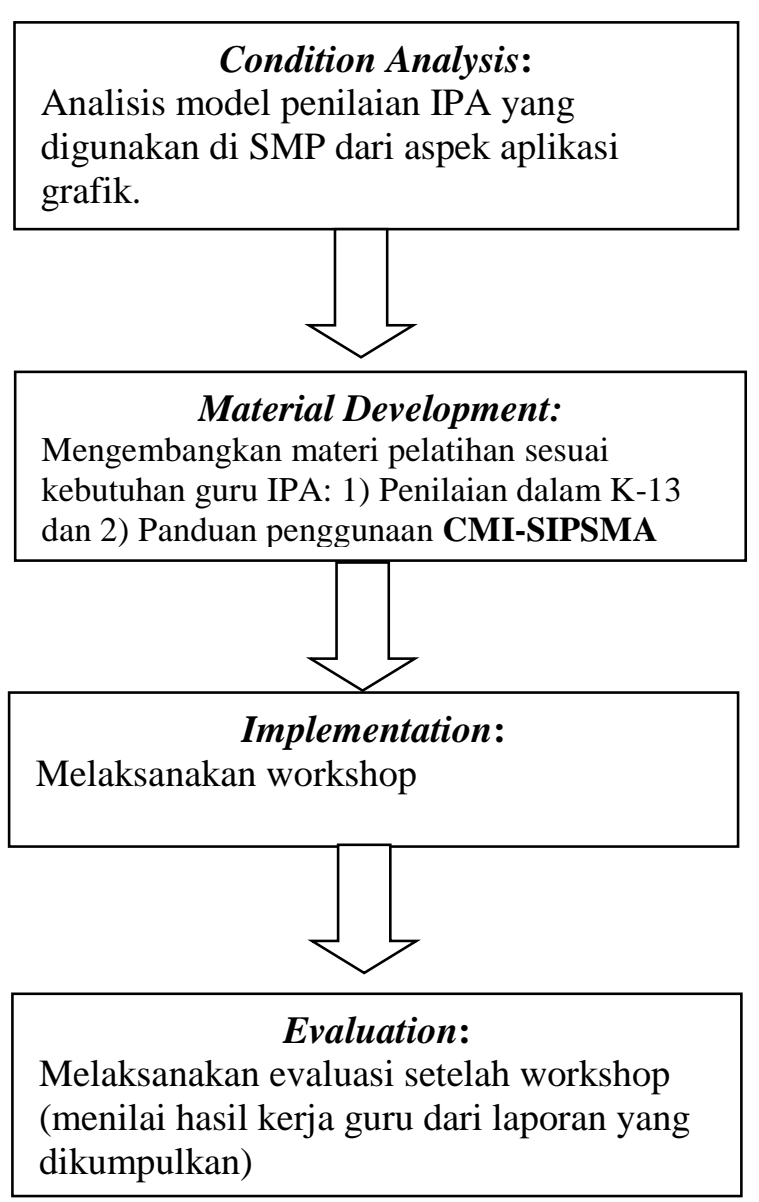

Gambar 1. Alur Pemecahan Masalah

Kegiatan PPM dilaksanakan dengan cara tutorial (Tatap Muka), workshop, penugasan terstruktur, dan konsultasi dengan rincian sebagai berikut.

1. Tutorial dan workshop: materi 1 adalah system penilaian berdasarkan kurikulum 2013.

2. Tutorial dan workshop: materi 2 adalah penggunaan aplikasi CMI-SIPSMA untuk system penilaian hasil belajar siswa.

3. Tugas Terstruktur:

a. Penyusunan model penilaian hasil belajar siswa untuk mata pelajaran IPA berdasarkan kurikulum 2013.

b. Penggunaan aplikasi CMI-SIPSMA untuk analisis butir soal IPA: 1) 
berbasis Excell, 2) berbasis Iteman, dan 3) berbasis quest.

4. Konsultasi Tugas: konsultasi dilakukan via email/HP, khususnya bagi peserta pelatihan yang mengalami kesulitan dalam menyelesaian tugas terstruktur.

Evaluasi dan refleksi kegiatan pelatihan dilakukan secara menyeluruh baik sebelum maupun setelah program selesai. Tim PPM akan melihat kondisi awal guru terhadap sistem penilaian yang telah diterapkan di sekolah dengan menggunakan angket. Demikian juga untuk mengetahui penguasaan guru dalam menggunakan aplikasi CMI-SIPSMA, guru mengisi angket lagi yang diberikan oleh Tim PPM. Keberhasilan kegiatan ini ditandandai dengan kepahaman dan keterampilan guru terhadap penggunaan aplikasi CMISIPSMA.

\section{HASIL DAN DISKUSI}

PPM yang telah dilaksanakan ini merupakan PPM berbasis pelatihan yang bersifat aplikatif bagi Guru SMP di Sleman. Sebelum PPM dilaksanakan, TIM PPM melakukan koordinasi persiapan segala sesuatu yang dibutuhkan untuk kegiatan baik sebelum maupun saat pelaksanaan. Persiapan yang dilakukan oleh Tim PPM mencakup aspek akademik, administrasi, dan non-akademik. Aspek akademik yang disiapakan meliputi: pemateri utama, makalah/materi dalam bentuk ppt, komputer (bagi peserta pelatihan disediakan komputer di laboratorium komputer IPA), dan lembar penilaian/monitoring. Persiapan administrasi mencakup lembar presensi, keperluan pertanggungjawaban keuangan, dan sertifikat untuk peserta. Persiapan nonakademik mencakup ruang, LCD, dan konsumsi. Tim PPM dalam hal ini terdiri dari dosen, mahasiswa, dan laboran Lab. IPA.

Pelatihan dilakukan di Laboratorium Komputer Jurusan Pendidikan IPA FMIPA, UNY, dilanjutkan dengan bimbingan terstruktur dengan on-line atau e-mail bagi peserta yang mengalami kesulitan dalam menyelesaiakan tugas. Pelatihan ini diikuti oleh 10 peserta dari target 20 peserta dari guru-guru IPA SMP di Sleman, Yogyakarta. Dengan berbagai keterbatasan maka peserta dibatasi sebanyak 20 orang saja. Pembatasan terkait dengan alokasi dana yang terbatas, dan keterbatasan sarana dan prasarana yang dimiliki. Pelaksanaan kegiatan ini terdapat faktor pendukung dan penghambat sebagai berikut.

1. Faktor Pendukung :

a. Jumlah komputer lebih dari cukup, sehingga semua satu peserta menggunakan satu komputer.

b. Motivasi peserta untuk menjadi guru IPA yang professional yang ditandai dengan banyak peserta yang bertanya selama pelatihan.

c. Kepakaran tim pengabdi sesuai dengan program pelatihan yang diselenggarakan.

2. Faktor Penghambat

a. Padatnya jadwal guru di sekolah, sehingga susah menentukan jadwal pelatihan.

b. Hari pelaksanaan PPM bersamaan dengan agenda Dinas Pendidikan sedingga peserta yang mengikuti pelatihan di bawah target.

Hasil kegiatan PPM ini yaitu guru memiliki pemahaman dasar tentang problem dan solusi dalam implementasi penilaian berdasarkan K-13 dan memiliki kemampuan menggunakan aplikasi yang ada di CMI SIPSMA untuk analisis butir soal untuk menghasilkan butir soal yang berkualitas. Sebelum pelatihan diakhiri, Tim PPM meminta tanggapan dari peserta pelatihan secara lisan dan lembar isian terhadap kegiatan pelatihan yang telah dilaksanakan. Secara ringkas hasil tanggapan guru dapat disimpulkan baik dan mendukung kompetensi guru untuk melakukan analisis butir soal sebagai salah satu tuntutan di K13 untuk menghasilkan butir soal yang berkualitas. Hasil analisis lembar isian menyatakan bahwa kegiatan PPM sangat dibutuhkan oleh peserta pelatihan/ guru untuk memenuhi salah satu kewajiaban dalam kenaikan pangkat. Harapan peserta 
pelatihan adalah kegiatan ini bisa dilanjutkan di waktu lain dengan tema yang serupa diantaranya pelatihan pengembangan butir soal keterampilan proses sains dan rubrik keterampilan proses sains untuk kegiatan di laboratorium.

\section{KESIMPULAN}

Berdasarkan uraian sebelumnya
dapat disimpulkan bahwa Program Pengabdian (PPM) telah terlaksana dengan hasil yang baik. Hasil penilaian melalui lisan, lembar isian, serrta hasil pengumpulan tugas terstruktur dari guru-guru peserta pelatihan, dapat disimpulkan bahwa PPM dengan yang dilakukan mampu memberi pemahaman dasar prosedur menggunakan aplikasi yang ada di CMI SIPSMA khususnya Anbuso dan Quest untuk analisis butir soal untuk menghasilkan butir soal yang berkualitas.

Kemampuan dan ketrampilan guru IPA dalam melakukan penelitian di kelas saat ini perlu didukung oleh penguasaan uji statistik yang memadahi. Penguasaan tersebut menjadi dasar untuk penyusunan karya ilmiah bagi guru. Berdasar fakta-fakta tersebut di atas maka direkomendasikan beberapa hal sebagai berikut.

a. Kegiatan PPM dilakukan secara rutin dilaksanakan untuk topik yang berbeda dengan diperluas sasaran dan wilayahnya.

b. Perlu dilakukan pelatihan pengelolaan laboratorium IPA

c. Pelatihan dengan memanfaatan ICT untuk pembelajaran

d. Pelatihan bedah soal/ kisi-kisi soal Olimpiade Sains SMP.

e. Perlu diintensifkan kemitraan antara FMIPA UNY dengan Pemda Propinsi atau Kabupaten/Kota dalam program pre-service, in-service maupun onservice training, sehingga akan terbentuk mutual relationship antar institusi yang terlibat.

\section{UCAPAN TERIMA KASIH}

Tim Pengabdian Kepada Masyarakat mengucapkan terima kasih kepada FMIPA UNY yang telah membiayai kegiatan ini melalui anggaran DIPA Universitas Negeri Yogyakarta, Ketua, Sekretaris, dan guru MGMP IPA SMP se- Kota Sleman, Yogyakarta.

\section{PUSTAKA}

Iftikhar Uddin Khwaja. (2013). Curriculum Development, Assessment and Evaluation. Islamabad: Iqra University Quetta.

Kelitbang. 2013. Kurikulum 2013. Jakarta: Kemdikbud.

Dadan Rosana. 2013. Evaluasi Pembelajaran Sains. Jakarta: Universitas Terbuka.

Kemdikbud. 2016. Pedoman Penilaian Kurikulum 2013. Jakarta: Kemdikbud.

Dadan Rosana \& Sukardiyono. 2015. Laporan Penelitian Hibah Kompetensi "Model Assessment Terstandar Berbasis Computer Management Instructional untuk Menjamin Kesetaraan Kualitas Penilaian Sebagai Basis Data Penentuan Kelulusan Dalam Sistem Ujian Akhir Nasional dan Snmptn Jalur Undangan Yang Berkeadilan". Yogyakarta: LPMP UNY.

Riddle, Dru; Baker Kathy; \& Sapp, Alysha. 2016. Evaluation of Testing as a Method to Assess Continued Competency in Nurse Anesthesia Practice: A Systematic Review. AANA Journal August 2016 Vol. 84, No. 4 